\title{
“OF AL THE KNOTTES THAT I SE / I PRESE THE KNOT IN TRINITE": TRINITARIAN ICONOGRAPHY IN THE MIDDLE ENGLISH LYRIC, AN AUNGELL FRO HEUEN GAN LYTH
}

\author{
Natalie Jones*
}

\begin{abstract}
The fifteenth-century carol An aungell fro heuen gan lyth is remarkable for the way in which it explores the Economy of Salvation and the triune power of the Godhead through the iconographic motif of the Trinitarian knot. This motif, derived from the "threefold cord" which "is not easily broken" (Eccles. 4.12), was developed by Petrus Alfonsi, Joachim of Fiore, and Dante in a Trinitarian context. An aungell fro heuen gan lyth is not only informed by this complex strand of Trinitarian iconology, but is also notable for its sophisticated handling of the motif. The Trinitarian knot is central to the carol's burden, but also recurs throughout the five stanzas, where it serves as a meditative device which celebrates the five great mysteries of faith enshrined in the Apostles' Creed. These mysteries, described in turn through the narrative progression of the carol, are encapsulated in successive variations on the Trinitarian knot.

Keywords: Middle English carol, An aungell fro heuen gan lyth, Trinitarian knot, Trinitarian iconology, Apostles' Creed, Incarnation, Crucifixion, Resurrection, Ascension, Last Judgment.
\end{abstract}

The corpus of Middle English religious lyrics is vast, diverse, and exceptionally rich in its customization of well-established iconographic motifs, often informed by intricate doctrinal argument, and exegetical complexity. Although these poems have often in the past been dismissed as humble, workaday, spiritual aids, which are devotionally and thematically simplistic, ${ }^{1}$ a close examination of the iconological significance of key motifs employed in many lyrics belies such a general dismissal. Indeed, the richness of allusion and iconological sophistication which characterize these lyrics requires us to examine each poem on its own terms, and engage with the wealth of scripture and tradition which informs it. This approach is particularly apt in the case of a little-known fifteenth-century carol, An aungell fro heuen gan lyth. ${ }^{2}$

That An aungell fro heuen gan lyth has failed to attract the attention of previous generations of scholars may be down to the fact that it has rarely been anthologized, and only survives in one manuscript: Oxford, Bodleian Library, MS Eng. poet. e.1. ${ }^{3}$ This small, paper manuscript dates from the second half of the fifteenth century and contains an assortment of secular and religious songs and verse, many of which take the form of carols and are written in the vernacular. In contradistinction to the majority of its contents, MS Eng. poet. e. 1 has been the subject of some critical debate and has traditionally been classified as a songbook: Thomas Wright, the nineteenth-century

\footnotetext{
*Department of English Language and Literature, University College London, Gower Street, London, WC1E 6BT, natalie.jones@ucl.ac.uk. In addition to the readers and editors, I am particularly grateful to Anne Marie D'Arcy, for her advice and support in the preparation of this article for publication, and Alan J. Fletcher, who offered many helpful suggestions when this article was in its early stages.

${ }^{1}$ See, for instance, Frank Allen Patterson, The Middle English Penitential Lyric (New York 1911) 26; G. L. Brook, The Harley Lyrics: The Middle English Lyrics of MS Harley 2253 (Manchester 1948) 17. See also Rosemary Woolf, The English Religious Lyric in the Middle Ages (Oxford 1968) 11, 13; Douglas Gray, Themes and Images in the Medieval English Religious Lyric (London 1972) 60.

${ }^{2}$ See The Early English Carols, ed. Richard L. Greene, 2nd ed. (Oxford 1977) 175, no. 282. The text of the poem is included as an appendix to this essay.

${ }^{3}$ In addition to Greene's anthology, the carol is reproduced in Songs and Carols Now First Printed from a Manuscript of the Fifteenth Century, ed. Thomas Wright (London 1847) 45-46, which is an edition of MS Eng poet. e.1. It is also found in Karl Breul, "Zwei mittelenglische Christmas Carols," Englische Studien 14 (1890) 404-405.
} 
antiquarian, suggested that the manuscript "in all probability belonged to a professed minstrel," while Rossell Hope Robbins described it as a "minstrel collection," grouping it with London, British Library MS Sloane 2593, and Cambridge, St John's MS S.54, which contain similar verse collections. ${ }^{5}$ Although a good proportion of the manuscript's contents are religious in theme, there are also a number of moral and secular lyrics, including anti-feminist poems and drinking songs. Certainly, the manuscript's portability, the inclusion of some musical notation, and the free arrangement of the material might imply a clerical functionality; it is possible that its content was collected together in order to be read and used regularly. ${ }^{6}$ An aungell fro heuen gan lyth is preserved in the manuscript on folio 31r, forming part of a group of six carols which make reference to Christ and the Virgin. ${ }^{7}$ It is one of the more striking lyrics in this group, as it explores the Economy of Salvation and the power of the Trinity through the motif of the Trinitarian knot; as the burden states: "Off al the knottes that I se / I prese the knot in Trinite" (lines a-b).

Although this carol has not been the subject of detailed, critical discussion until now, Richard L. Greene is one of the few scholars who has commented on its imagery, pointing to the Christological emphasis of the stanzas. He suggests that the knot motif "carries the implication of Christ's perfect love," and is analogous to the imagery found in Thomas Usk's prose treatise, The Testament of Love. ${ }^{8}$ While Greene is certainly correct that the carol's five stanzas are predominantly Christological in focus, his assessment is in need of some refinement, as a detailed examination of the lyric reveals a subtle modulation in tone between the main body of the poem and its burden. Indeed, as the knot imagery recurs throughout the carol's five stanzas it comes to be invested with several meanings, each of which is carefully related to the devotional and theological concerns of the stanza in which it appears. Thus, rather than focusing solely on "Christ's perfect love," the carol is deep with theological and iconographic significance and serves not just as a means of devotional expression, but as a powerful declaration of faith: as we shall see, through the sequence of five stanzas the carol's author celebrates the five great mysteries of the faith enshrined in the Apostles'

\footnotetext{
${ }^{4}$ Wright, Songs and Carols (n. 3 above) v.

${ }^{5}$ Rossell Hope Robbins, Secular Lyrics of the XIVth and XVth Centuries, 2nd ed. (Oxford 1955) xxxvixxvii; see also Andrew Taylor, "The Myth of the Minstrel Manuscript," Speculum 66 (1991) 60-65. This view has been challenged by Greene, Early English Carols (n. 2 above) 318, who suggests that the manuscript was produced in a clerical milieu, linking its production to the secular canons at Beverly Minster in Yorkshire. While the argument for a clerical milieu is convincing (see Julia Boffey, "Middle English Lyrics and Manuscripts," A Companion to the Middle English Lyrics, ed. Thomas G. Duncan [Cambridge 2005] 15-16), the suggestion that the manuscript was produced at Beverley Minster is largely conjectural. Rather, in view of more recent work, it seems more likely that the manuscript may have links to Norfolk; see Richard Beadle, "Prolegomena to a Literary Geography of Later Medieval Norfolk," Regionalism in Late Medieval Manuscripts and Texts: Essays Celebrating the Publication of the Linguistic Atlas of Later Middle English, ed. Felicity Riddy (Cambridge 1991) 106; Daniel Wakelin, "The Carol in Writing: Three Anthologies from Fifteenth-Century Norfolk,” Journal of the Early Book Society 9 (2006) 28 n. 13.

${ }^{6}$ See Boffey, "Lyrics and Manuscripts" (n. 5 above) 15-16.

${ }^{7}$ See Wright, Songs and Carols (n. 3 above) 44-51. This discrete unit of poems may reflect the use of an exemplar. It is also worth noting that the first poem of this cluster, beginning Thow thou byst kyng, and were the crowne, is perhaps better categorized as a moral poem, which repeatedly emphasizes the need to repent "for Crystes sake" (1. 5).

${ }^{8}$ Greene, Early English Carols (n. 2 above) 413. See also Thomas Usk, The Testament of Love, ed. John Leyerle and Gary W. Shawver (Toronto 2002) 92-93.
} 
Creed. ${ }^{9}$ These mysteries of the birth and death of Christ, the Resurrection, the Ascension, and the Parousia, or Second Coming, are not only described in turn through the narrative progression of the carol, but are also presented symbolically through a succession of variations on the Trinitarian knot motif. ${ }^{10}$ Thus, when we read the stanzas alongside the burden, the carol proves itself to be a highly sophisticated poem that is underpinned by a complex theology, offering a powerful assertion of the role of the triune Godhead in the Plan of Salvation.

In order to demonstrate the complexity at work in An aungell fro heuen gan lyth, this discussion will initially trace the origin and development of the Trinitarian knot motif in a nexus of visual and literary traditions, before turning to examine its use and significance throughout the carol's five main stanzas. However, it is necessary to begin by considering the carol's burden in detail. Typically written down at the head of the poem, and sung or recited before the first stanza and then repeated after all subsequent stanzas, the burden is the distinguishing feature that "makes and marks the carol." 11 As Greene notes, any analysis of the burden of a carol, which is often distinguished by its "quasi-independent character," is "best made by isolating them to some extent from their associated stanza-texts."12 Such an approach is especially fruitful when we turn to examine the two-line burden of An aungell fro heuen gan lyth: "Of al the knottes that I se / I prese the knot in Trinite" (lines a-b). Although this rhyming couplet serves as an overt declaration of praise, the depiction of the relationship between the three persons of the Godhead as a knot is also an apposite expression of Trinitarian doctrine, as it neatly encapsulates the indivisibility of the triune God: the Father, Son, and Holy Spirit are one, intertwined like an endless knot. It should also be noted that the appropriateness of the knot motif as an expression of Trinitarian doctrine is furthered in a Middle English context due to the semantic potentiality of the term "knotte." As the Middle English Dictionary states, the term "knotte" could mean "a knot tied in a rope or thread ... for binding,",13 but could also signify "a bond between persons" and "agreement," "14 thus neatly evoking the indissoluble unity of the three persons in the one Godhead. However, although an awareness of the polysemy of the term "knotte" in Middle English is crucial in aiding our understanding of the carol's imagery, the motif of the Trinitarian knot can only be fully understood in relation to a longstanding tradition of Trinitarian symbolism, rooted in the patristic exegesis of scriptural imagery. Thus before considering how the burden works in connection with the stanzas, it is worth pausing to reflect on the background to the burden's central motif of the Trinitarian knot.

The origins of the Trinitarian knot motif can be traced back to the early Church, where the precise nature and interrelationship between the three hypostases, or three persons in the one Godhead, was itself seen as rather "knotty," complex, and in need

\footnotetext{
${ }^{9}$ The Creeds of Christendom, ed. Philip Schaff, 3 vols. (New York 1877) 1.21.

${ }^{10}$ See Breul, "Zwei mittelenglische Christmas Carols" (n. 3 above) 405.

${ }^{11}$ Greene, Early English Carols (n. 2 above) clx. As Greene reminds us, the carol genre can be defined as "a song on any subject, composed of uniform stanzas and provided with a burden" (xxxii-xxxiii).

12 Ibid. clx.

${ }^{13}$ MED, s.v. "knotte" (n), definition 1 (a): "A knot tied in a rope, thread, web, etc., for binding or fastening."

${ }^{14}$ Ibid. s.v. "knotte" (n), definition 3 (c).
} 
of definition. This was especially the case during the formative centuries of Christianity, as the Church was adrift in a sea of theological controversy and heresy which directly challenged the establishment of the faith, especially in relation to Trinitarian doctrine, a dogma not explicitly grounded in the books of the New Testament. ${ }^{15}$ In an attempt to overcome this lack of definition, many patristic exegetes sought evidence of the Trinity in the Old Testament, pointing to a number of passages which suggested hypostasis, such as Proverbs 8.22-31. ${ }^{16}$ However, the veiled nature of these Old Testament verses meant that they were open to a variety of interpretations and could thus be cited by orthodox and heterodox writers alike in support of their contrasting views. Indeed, Proverbs $8.22-31$ was deployed by the Arians to defend their belief that Christ was a created being and therefore subordinate to the Father. ${ }^{17}$ Although the fundamental tenets of Trinitarian doctrine were defined partly in opposition to various heterodox interpretations of scripture, ${ }^{18}$ the orthodox position was most powerfully asserted by the First Council of Nicaea in 325, and then refined at the First Council of Constantinople in 381. Prior to the Council of Constantinople, especially in the East, the Greek terms hypostasis ("person") and ousia ("essence") were often used interchangeably as synonyms for that which subsists. ${ }^{19}$ The precise meaning of the term ousia in the Nicene Creed was even a source of conflict, as some Arian bishops argued that the declaration that Christ is homoousios, that is, of one being or essence with the Father, failed to distinguish adequately between the three persons and was thus tainted with the Monarchian and Sabellian heresies. ${ }^{20}$ It is generally accepted that the problems arising from the wording of the Nicene Creed were resolved by the Cappadocian Fathers, who sought to refine the formula of triunity by developing a more discriminating terminology: "the common is to be understood as referring to the essence; the hypostasis on the

\footnotetext{
${ }^{15}$ The New Testament contains several passages which were taken as evidence of the existence of the Trinity, but nowhere outlines the nature of the three persons and their interrelationship. See Luke 3.21-22; John 15.26; 1 Cor 6.11; 1 Cor 15.27-28; 2 Cor 13.13; Gal 3.11-14; Heb 10.29; 1 Pet 1.2; 1 John 5.7. On the place of the Trinity in the New Testament, see Harry Austryn Wolfson, The Philosophy of the Church Fathers, Volume One: Faith, Trinity, Incarnation, 3rd ed. (Cambridge, MA 1970) 147-148; Peter C. Phan, "Developments of the Doctrine of the Trinity," The Cambridge Companion to the Trinity, ed. Peter C. Phan (Cambridge 2011) 3-4.

${ }^{16}$ See also Gen 1.1-3, 1.26, 3.22; Ps 2.7; Isa. 63.9. On Prov 8.22-31, see Tertullian, Adversus Praxean 6, ed. E. Dekkers and E. Evans, CCSL (Turnhout 1954) 2.1164-1165; Hilary of Poitiers, De Trinitate, 12. 36-39, PL 10.454-458.

${ }^{17}$ The Arian use of Proverbs $8.22-31$ is mentioned by Hilary of Poitiers: "They argue that He is a creature, because it is written, 'The Lord hath created Me for a beginning of His ways'; that He is a perfect handiwork of God, though different from His other works." De Trinitate 4. 11, PL 10.104; trans. E. W. Watson, L. Pullan et al., A Select Library of the Nicene and Post-Nicene Fathers of the Christian Church, ed. Philip Schaff and Henry Wace, 1st ser. 14 vols., 2nd ser. 14 vols. (New York 1899; repr. Grand Rapids 1955) 2.9, 74. See also Jaroslav Pelikan, The Emergence of the Catholic Tradition (100-600) (Chicago 1971) 193-197.

${ }^{18}$ See Tertullian, Adversus Praxeam, CCSL 2.1159-1205; Hippolytus of Rome, Contra Noetum, ed. and trans. Robert Butterworth (London 1977) 74-82.

${ }^{19}$ See Pelikan, Emergence (n. 17 above) 219; Phan, "Developments of the Doctrine of the Trinity" (n. 15 above) 8 .

${ }^{20}$ See Nicene Creed, Decrees of the Ecumenical Councils, ed. Norman P. Tanner and Giuseppe Alberigo et al., 2 vols. (London 1990) 1.5. On the interpretation of and opposition to homoousios, see Pelikan, Emergence (n. 17 above) 218-219. See also Pier Franco Beatrice, "The Word 'Homoousios' from Hellenism to Christianity," Church History 71 (2002) 243-272. Although homoousios was understood by many bishops to mean "of one substance," as opposed to "of one person," the term was trenchantly opposed by the Arians; see Basil of Caesarea's letter to Count Terentius, Epistle 214. 3-4, PG 32.787-790.
} 
other hand is the several distinctive sign. ${ }^{21}$ Henceforth it could be said that God existed in one ousia and three hypostaseis and the Cappadocian solution was ratified at the Council of Constantinople. It was later reaffirmed in the so-called Athanasian Creed, composed sometime between the mid-fifth and mid-sixth centuries. ${ }^{22}$

After the Church's formal declarations of Trinitarian doctrine at the Council of Constantinople and the specific response of the so-called Athanasian Creed, exegetes began to interpret scriptural passages which employed threefold motifs as evidence of the triune Godhead. ${ }^{23}$ For instance, Abraham's heavenly visitors in Genesis 18.1-3, and the chant of the seraphim of "Holy, Holy, Holy" in Isaiah 6.3, were both glossed as Trinitarian symbols. ${ }^{24}$ It is in this exegesis that we find the earliest precursor to the Trinitarian knot motif, as the "threefold cord," which "is not easily broken" in Ecclesiastes 4.12, was also understood as a figure of the Trinity. ${ }^{25}$ Indeed, the Trinitarian significance of this particular verse is elucidated by St Ambrose who reminds us, "Threes which are not compounded are not broken. The Trinity of an uncompounded nature cannot be broken, because God is whatever is one and simple and not compounded, which continues to be what it is, and is not destroyed."26 For Ambrose, the "threefold cord" encapsulates the indivisibility of the three persons and symbolizes their coequality, coeternity, and consubstantiality. Ambrose's emphasis on the "uncompounded nature" of the Trinity is developed by Gregory the Great, who interprets the "threefold cord" of unity as a sign of true faith, bound in the hearts of believers: "the faith in truth that is woven by the mouths of preachers from the knowledge of the Trinity, remain[s] firm in the Elect." 27

Although the Trinitarian knot motif clearly owes a debt to this scriptural image, it is also informed by a strand of early Christian iconography which uses interlacing lines, or geometric shapes, to convey triunity. As Didron points out, one of the earliest signs used to represent the Trinity was the equilateral triangle: "the triangle, comprehending three angles in one single area, is a correct image of the three persons, resolving themselves into one single God. ${ }^{, 28}$ However, because the triangle was linked to the Trinity by the Manicheans, it was condemned by Augustine, and was generally avoided as a

${ }^{21}$ Basil of Caesarea, Epistle 38. 5, PG 32.335; trans. Blomfield Jackson, Nicene and Post-Nicene Fathers 2.8, 140.

${ }^{22}$ See the description of the decrees of the Council of Constantinople by Hermias Sozomen, Historia ecclesiastica 7. 9; trans. C. D. Hartranft, Nicene and Post-Nicene Fathers 2.2, 381. The precise date of composition for the Athanasian Creed is unknown, although it has been suggested that it was written soon after $440 \mathrm{AD}$, possibly at Lérins; see J. N. D. Kelly, The Athanasian Creed (New York 1965) 123. See also Pelikan, Emergence (n. 17 above) 351-352.

${ }^{23}$ See Adolphe Napoléon Didron, Christian Iconography: The History of Christian Art in the Middle Ages, trans. Margaret Stokes, 2 vols. (London 1886) 2.20-21.

${ }^{24}$ Ibid. 2.20-21. On Isa 6.3 as a figure of the Trinity, see Ambrose, De Spiritu Sancto 3. 16. 110, CSEL (Vienna 1866-) 79.196-197; Theodoret of Cyrus, Commentarius in Isaiam 6. 3, Source chrétiennes (Paris 1940-) 276.260-262; Cyril of Alexandria, Commentarius in Isaiam Prophetam 1. 4, PG 70.173-174. On the Trinitarian significance of Gen. 18.1-3, see Ambrose, De Fide 1. 13. 80, CSEL 78.35; Augustine, De Trinitate 2. 10, CCSL 50.105-106; Caesarius of Arles, Sermo 83. 5, CCSL 104.342-343.

${ }^{25}$ All biblical quotations in English are taken from the Douay-Challoner translation of the Vulgate.

${ }^{26}$ Ambrose, Epistle 81. 8, PL 16.1330; trans. Mary Melchior Beyenka, Saint Ambrose: Letters (Washington, DC 1954) 319.

${ }^{27}$ Gregory the Great, Moralia in Job 33. 10. 18, CCSL 143B.1689; trans. James Bliss and Charles Marriott, Morals on the Book of Job by St Gregory the Great, 3 vols. (Oxford 1844-1850) 2.573-574.

${ }^{28}$ Didron, Christian Iconography (n. 23 above) 2.41. 
Trinitarian symbol in the West until at least the eleventh century, only becoming commonplace in the sixteenth and seventeenth centuries. ${ }^{29} \mathrm{~A}$ less controversial symbol was the triquetra, which is similar in outline to the triangle, albeit formed by the interlacing of a single, continuous line, as demonstrated by numerous examples in a Trinitarian context in such manuscripts as the Book of Dimma, the Lindisfarne Gospels, and the Book of Kells. ${ }^{30}$ The triquetra resonated with Trinitarian significance: not only was it formed of three, intersecting vesicae piscis, but its three equal arches, interwoven into an endless knot, aptly conveyed the coequality, coeternity, and consubstantiality of the triune Godhead.

However, in spite of the popularity of the triquetra, especially in Insular art, the circle was the principal geometric shape which informed the iconography of the Trinity, and the Trinitarian knot in particular. From the classical period onward, the circle was regarded as the most perfect geometric shape, possessing the highest degree of symmetry; thus, it served as an emblem of absolute unity. ${ }^{31}$ As several scholars have noted, the appropriation of the circle as a symbol of triunity is employed as early as Augustine in his treatise, On the Trinity:

These three, therefore, must needs be of one and the same essence; and for that reason, if they were confounded together as it were by comingling, they could not be in any way three, neither could they be mutually referred to each other. Just as if you were to make from one and the same gold three similar rings, although connected with each other, they are mutually referred to each other, because they are similar. For everything similar is similar to something, and there is a trinity of rings, and one gold. ${ }^{32}$

By the twelfth century, On the Trinity had become one of the principal texts of the studium, which may explain why the Trinitarian symbol of three circles is given such prominence in the work of Petrus Alfonsi and Joachim of Fiore, culminating in the celestial vision of Dante Alighieri. ${ }^{33}$ The Trinitarian images envisaged by Alfonsi, Joachim, and Dante are especially interesting from an iconographic perspective because, in spite of their specific differences, the three circles are carefully positioned to produce an arrangement resembling a Trinitarian knot. The earliest and perhaps the

\footnotetext{
${ }^{29}$ On Augustine's condemnation of the Manicheans's triangular formula, see Contra Faustum Manichaeum 20. 7, CSEL 25.541-542. See also Beatrice Hirsch-Reich, "The Symbolism of Musical Instruments in the Psalterium X Chordarum of Joachim of Fiore and its Patristic Sources," Studia Patristica 9: Papers Presented to the Fourth International Conference on Patristic Studies held at Christ Church, Oxford, 1963, ed. Frank L. Cross (Berlin 1966) 542; Adam S. Cohen, The Uta Codex: Art, Philosophy, and Reform in Eleventh-Century Germany (Philadelphia 2000) 32-33. On the reemergence of the triangle in an early modern context, see Kristen Poole, Supernatural Environments in Shakespeare's England: Spaces of Demonism, Divinity, and Drama (Cambridge 2011) 186-196.

${ }^{30}$ See Mildred Budny, "Deciphering the Art of Interlace," From Ireland Coming: Irish Art from the Early Christian to the Late Gothic Period and its European Context, ed. Colum Hourihane (Princeton 2001) 197.

${ }^{31}$ See Lynne Ballew, Straight and Circular: A Study of Imagery in Greek Philosophy (Assen 1979) passim; Dennis J. Schmidt, "Circles - Hermeneutic and Otherwise: On Various Senses of the Future as 'Not Yet," Writing the Future, ed. David Wood (London 1990) 67.

${ }_{32}$ Augustine, On the Trinity, 9. 5. 7, CCSL 50.299-300; trans. Arthur West Hadden, Nicene and PostNicene Fathers 1.3, 128. See also Peter Cromwell, Elisabetta Beltrami and Marta Rampichini, "The Borromean Rings," The Mathematical Intelligencer 20 (1998) 53-63.

${ }^{33}$ In addition to Cromwell, Beltrami and Rampichini, "Borromean Rings" (n. 32 above) 59, see Marjorie Reeves and Beatrice Hirsch-Reich, The Figurae of Joachim of Fiore (Oxford 1972) 40-42, 323-325; John Victor Tolan, Petrus Alfonsi and his Medieval Readers (Gainesville 1993) 113-114.
} 
most straightforward of these diagrams is found in chapter six of Dialogues Against the Jews by Petrus Alfonsi, the twelfth-century astronomer, physician and scholar of the liberal arts, who converted from Judaism to Christianity in adulthood. ${ }^{34}$ Alfonsi's diagram accompanies a discussion of the Trinitarian significance of the tetragrammaton: the sacred, ineffable name of the Lord usually written as YHWH, although Alfonsi writes it as IEUE. ${ }^{35}$ In order to demonstrate that the tetragrammaton reveals the three persons of the Godhead, Alfonsi constructs a diagram of three circles linked in a triangular formation, each emblazoned with a pair of letters taken from the tetragrammaton (IE, EU, UE) (Fig. 1). ${ }^{36}$ According to Alfonsi the tripartite division of IEUE across the three circles perfectly encapsulates the mystery of the Trinity, as although the sacred name can be divided into three parts, each part comes together to form a cohesive whole, as demonstrated by the inclusion of the tetragrammaton in the diagram's center: "you will see that this same name is both one and three ... that one refers to the unity of the substance, whereas the three refer to the trinity of persons." Alfonsi's emphasis on the distinct yet unified parts of the tetragrammaton clearly informs the intricacies of the diagram's structure; not only are the three persons distinguished by the three circles in their triangular arrangement, but the unity of the Godhead is also emphasized in the bold, straight lines which link the circles, producing a figure that is unified, balanced, and equal.

The interconnected structure found in Alfonsi's diagram is even more apparent in the Trinitarian symbol attributed to the twelfth-century theologian and abbot, Joachim of Fiore. ${ }^{38}$ In his Exposition on the Apocalypse, Joachim presents his conception of Trinitarian doctrine through a figure of three circles containing the pairs of letters taken from the tetragrammaton, IEUE; a feature which Joachim directly attributes to his reading of Alfonsi. ${ }^{39}$ Unlike Alfonsi's triangular diagram, however, Joachim arranges his three circles in a linear formation and neatly overlaps them to create a complex, interwoven figure (Fig. 2). ${ }^{40}$ This knot-like diagram helps to convey some of the

${ }^{34}$ On the life and works of Petrus Alfonsi see Tolan, Petrus Alfonsi (n. 33 above) xiii-9.

${ }^{35}$ See Petrus Alfonsi, Dialogi Contra Iudeaos 6, PL 157.611. See also Tolan, Petrus Alfonsi (n. 33 above) 240 n. 45 , who notes that the tetragrammaton as IEUE is common to all manuscripts of the Dialogi contra Judaeos consulted, except for two, where it is given in Hebrew letters.

${ }^{36}$ As Tolan has pointed out, this diagram is a common feature of the extant copies of the Dialogus; see Petrus Alfonsi (n. 33 above) 38.

${ }^{37}$ Dialogi Contra Judeaos 6, PL 157.611; trans. Irven M. Resnick, Petrus Alfonsi: Dialogue Against the Jews (Washington, DC 2006) 72.

${ }^{38}$ See Morton W. Bloomfield, "Joachim of Flora: A Critical Survey of his Canon, Teachings, Sources, Biography and Influence," Traditio 13 (1957) 249-311; Marjorie Reeves, Joachim of Fiore and the Prophetic Future (New York and London 1977); Bernard McGinn, The Calabrian Abbot: Joachim of Fiore in the History of Western Thought (New York 1985).

${ }^{39}$ See Reeves and Hirsch-Reich, Figurae (n. 33 above) 40; Tolan, Petrus Alfonsi (n. 33 above) 114.

${ }^{40}$ Here, it is important to note that due to their reliance on the diagram in PL 157.611, Reeves and Hirsch-Reich misinterpret the precise relationship between Alfonsi's original, triangular diagram and that of Joachim, incorrectly stating that Alfonsi's comprised three linked circles arranged in a linear form, containing the pairs of letters taken from the tetragrammaton (written in Hebrew), circumscribed by one larger circle; see Figurae (n. 33 above) 42-43. Reeves and Hirsch-Reich believe the circular diagram reproduced in Migne is the direct source of Joachim's diagram, but as Tolan points out, this circular diagram is taken from a later manuscript of Alfonsi's work: "The Köln edition of 1536 (and hence PL) must have been based on a manuscript that had used Joachim's tricircular configuration and had retranscribed IEVE into Hebrew. No manuscript I have examined has the diagram in the form of interlocking circles, though two manuscripts 
complexity of Joachim's theology, as he viewed the Trinity in terms of a procession that spanned three overlapping historical epochs, each of which could be related to one of the three persons of the Godhead. ${ }^{41}$ Although his theory of historical progression accounts for the interweaving of the three circles, the overlapping construction of Joachim's diagram is grounded in orthodox Trinitarian doctrine: not only does each circle represent one of the three persons of the Godhead through the division of the name of the Lord, but, due to the diagram's linear arrangement, the three pairs of letters come together to reveal the completed tetragrammaton, which spans all of the three circles simultaneously. ${ }^{42}$ In spite of this orthodox foundation, Joachim's association of the Trinity with three historical epochs of his own conception proved problematic for the Latin Church, in contradistinction to the clear emphasis on the unity of the three persons in the work of Peter Lombard. ${ }^{43}$ In the eyes of the Church, Joachim's opaque theology only succeeded in obscuring the unity of the Trinity, leading to Tritheism, and his Trinitarian views were posthumously condemned as heretical by the Fourth Lateran Council in $1215 .^{44}$ In spite of Joachim's anathematization, his exegetical historiography and his Trinitarian diagrams remained highly influential, and may have been a source of inspiration for Dante. ${ }^{45}$ In particular, it has been suggested that Joachim's use of color finds a subtle parallel at the end of the Paradiso, where God is described as "tre giri di tre colori e d'una contenenza."

The Trinitarian images of Alfonsi, Joachim, and Dante exemplify the increasing tendency to conceive of the relationship of the three persons of the triune Godhead in terms of a range of interwoven motifs, including knots, from the twelfth century onward. Although a great deal of scholarly attention has been paid to the Trinitarian images of these three disparate, yet interconnected thinkers, the use of three circles to symbolize the Trinity was relatively widespread in the later Middle Ages, especially in the form of the Borromean rings: so called because they are the emblem of the Borromeo family. Although the Borromean rings were invested with a variety of meanings, they were widely regarded as a fitting symbol of the Trinity because the three rings

(P4 and P5) have the Hebrew letters"; Petrus Alfonsi (n. 33 above) 240 n. 45. Tolan's findings have been confirmed by Resnick, Dialogue Against the Jews (n. 37 above) 172-173 n. 24.

${ }^{41}$ Joachim typified Adam, Uzziah, and St Benedict as the precursors of the first, second, and third ages respectively, that is, the Age of the Father under the law of the Old Testament; the Age of the Son under the Grace of the New Testament; and the Age of the Spirit, which would be characterized by Love; see Bloomfield, "Joachim of Flora" (n. 38 above) 264-269.

${ }^{42}$ See Reeves and Hirsch-Reich, Figurae (n. 33 above) 192-198.

${ }^{43}$ See Marcia L. Colish, Peter Lombard, 2 vols. (Leiden 1994) 1.434. On Joachim's opposition to the theories of Peter Lombard, see E. Randolph Daniel, "The Double Procession of the Holy Spirit in Joachim of Fiore's Understanding of History," Speculum 55 (1980) 469-483; Harold Lee, "The Anti-Lombard Figures of Joachim of Fiore: A Reinterpretation," Prophecy and Millenarianism: Essays in Honour of Marjorie Reeves, ed. Ann Williams (London 1980) 129-142.

${ }^{44}$ See Canon 2, Decrees of the Fourth Lateran Council (1215), Decrees of the Ecumenical Councils (n. 20 above) 1.231. On Joachim's condemnation see Margery Reeves, The Influence of Prophecy in the Later Middle Ages: A Study in Joachimism (Oxford 1969) 28-36; Fiona Robb, "The Fourth Lateran Council's Definition of Trinitarian Orthodoxy," Journal of Ecclesiastical History 48 (1997) 22-43.

${ }^{45}$ In addition to Reeves and Hirsch-Reich, Figurae (n. 33 above) 323-324, see Beatrice Hirsch Reich, "Die Quelle der Trinitätskreise von Joachim von Fiore und Dante," Sophia 22 (1954) 170-178. See also Peter Dronke, The Medieval Poet and his World (Rome 1984) 98-104; Robert Wilson, Prophecies and Prophecy in Dante's Commedia (Florence 2008) 213-214.

46 "Three circles of three colours and of the same extent." Dante Alighieri, Paradiso, XXXIII 114-115, The Divine Comedy of Dante Alighieri, ed. and trans. John D. Sinclair, 3 vols. (Oxford 1961) 3.484. 
intertwined to form a Brunnian link: a complex knot which ensures that "the rings, when taken together, are inseparable; however, if any one ring is removed the other two fall apart." 47 An early example of the Borromean rings as a Trinitarian symbol was preserved in a thirteenth-century French manuscript (formerly Chartres, Bibliothèque Communale, MS 1355), until it was lost to fire in 1944. As illustrated by Didron's drawing, this diagram represents the three persons by means of three interlinked circles, between which the word trinitas is divided (in the form of tri, ni, tas) (Fig. 3). This division, which recalls the partition of the tetragrammaton found in Alfonsi and Joachim, is once again qualified by the emphasis on unity, reinforced by the inclusion of the word unitas in the central intersection of the three circles. Although the prevalence of this exact type of image is difficult to determine, we may note several more opaque allusions to the Borromean rings in the visual arts, most notably in the iconographic programmes of Gothic stonemasonry. Here, the outline of the Borromean rings corresponds exactly to that of the trefoil: a symbol of the Trinity found in sculpture and window tracery from the twelfth century onwards. Trefoils feature prominently in the development of English Gothic; we may note, for instance, trefoil arches in the Early English style at Hereford, Lincoln, Salisbury, and Westminster Abbey, and the myriad examples in the Decorated Style on the west façade of York Minster, which dates from the early fourteenth century. ${ }^{48}$

By the time An aungell fro heuen gan lyth was written down over a century later, the Trinitarian knot motif, particularly the Borromean rings, was not only familiar to English artists, but also to English writers. Indeed, although the carol is remarkable for its extended use of the knot motif, it is not the first Middle English text to employ it, as other Middle English authors deployed the motif as a symbol of the power and unity of the triune Godhead. For instance, we find the knot motif in John Trevisa's translation of Bartholomaeus Anglicus, in which the Holy Spirit is described as "pe knotte and loue of eyper pe fader and sone." 49 This imagery serves to emphasize the unity of the three persons as well as underline the filioque clause (that is, the belief that the Holy Spirit proceeds from the Son as well as the Father), which was originally confirmed at the second Council of Lyons in $1274 .^{50}$ The image of the knot is also found in Thomas Usk's Testament of Love, where it is God, rather than the Trinity

\footnotetext{
${ }^{47}$ Cromwell, Beltrami, and Rampichini, "Borromean Rings" (n. 32 above) 53.

${ }^{48}$ See Gertrude Sill, A Handbook of Symbols in Christian Art (New York 1975) 57; Derek Phillips, "The Tracery of the Great West Window at York Minster," Journal of the British Archaeological Association 152 (1999) 24-48.

49 On the Properties of Things: John Trevisa's Translation of Bartholomaeus Anglicus, De Proprietatibus Rerum, ed. M. A. Seymour et al., 3 vols. (Oxford 1975-1988) 2.1369. For the Latin, see Angelicus Barthomomaeus, De rerum Proprietatibus, ed. Pontanus a Braitenberg and Georgius Banholdus (Frankfurt am Main 1601; repr. Frankfurt am Main 1964) CXXVII, 1235: "Nam pater generat et genuit ab aeterno Filuim, et per Filium spirat spiritum sanctum, qui est ardor, id est, amor utruisque atque nexus."

${ }^{50}$ The idea of the filioque was the greatest point of controversy between the East and West, as Pelikan, The Growth of Medieval Theology (600-1300) (Chicago 1978) 279-280, states: "Among the various objections of Eastern theologians to the Latin idea of filioque, none was more sensitive than the charge that by introducing the notion of a procession of the Holy Spirit from the Son as well as from the Father, the West was making the Son a second 'source' or 'principle' or 'cause' within the Trinity and was thereby jeopardizing the unity of the Godhead." In an attempt to unite the Eastern and Western Churches, the Council of Basel-Ferrara-Florence in 1438-1445 asserted that the Holy Spirit proceeds from the Father and the Son as from one principle and in one procession. See Joseph Gill, The Council of Florence (Cambridge 1959).
} 
explicitly, who is described as the "knotte of al goodnesse." ${ }^{, 51}$ A further utilization of the symbol is found in the Shearman and Taylor's Corpus Christi pageant, which forms part of the Coventry Cycle and most probably dates from the fifteenth century. This pageant focuses on the events of the Annunciation and Nativity and uses the motif in one of its most widely recognizable forms. Indeed, here the Trinitarian knot is used to signify the moment of Christ's conception by drawing upon the popular depiction of the Virgin spinning or weaving thread as a metaphor for the Incarnation; as Gabriel announces to Mary: "For now ys the knott surely knytt / And God conseyvide in Trenete." ${ }^{, 52}$ Certainly, these three examples go some way to demonstrate that the Trinitarian knot, in various forms, was known to a number of English authors during the later Middle Ages, while its use in a popular, dramatic context suggests that it was also familiar to a contemporary audience.

In spite of this, An Aungell fro heuen gan lyth is certainly worthy of closer examination because it not only bears witness to contemporary familiarity with the Trinitarian knot and its meanings, but also offers a unique and highly creative interpretation of this motif: as noted above, it is used in a traditional Trinitarian context in the carol's burden, but also takes on a succession of meanings throughout the poem's five stanzas. Indeed, as we shall see, the main body of the carol is distinguished by its sophisticated, polysemous exploration of the term "knotte," which is used to evoke a broad range of devotional and theological concepts in line with the five great mysteries of the faith as expressed in the Apostles' Creed. The continual repetition of the knot motif throughout all parts of the carol is especially significant and serves to heighten the poem's devotional and theological message by solidifying the important link between the burden and the stanzas. On a structural level, this link is further reinforced through the recitation of the burden after each of the five stanzas and also by the use of rhyme as, in accordance with many carols of the period, the last line of each stanza rhymes with the couplet of the burden. ${ }^{53}$ These techniques serve to heighten the connection between the Christological focus of the stanzas and the Trinitarian emphasis of the burden, as the carol subtly underlines the two natures of the Godhead by placing Christ's life and Passion within the larger, theological framework of the Plan of Salvation and the mysteries of the triune Godhead. Thus, unlike many other lyrics of the fifteenth century that choose to focus exclusively on the physical ordeal Christ endured in the Passion, the carol's broad theological scope is particularly striking and reminds us that the redemption of mankind is not just the workings of Christ alone, but is effected through the power of the fullness of God in Trinity.

The emphasis on the Trinity's role in the Plan of Salvation is evident from the first stanza, where the carol focuses on the Annunciation and Mary's role as Theotokos:

${ }^{51}$ Thomas Usk, Testament of Love (n. 8 above) 121. The image of the knot is central to the second book of the Testament; see Claes Schaar, "Usk's 'Knot in the hert'," English Studies 37 (1956) 260-261.

${ }^{52}$ Shearman and Taylor's Corpus Christi Pageant, The Coventry Corpus Christi Plays, ed. Pamela M. King and Clifford Davidson (Kalamazoo 2000) 85, lines 88-89. See also the 15th-c. lyric, Ecce ancilla domini, which also uses the Trinitarian knot motif to mark the moment of conception at the Annunciation: "At that worde knot was knitte"; Religious Lyrics of the Fifteenth Century, ed. Carleton Brown (Oxford 1939) 105-106, line 55.

${ }^{53}$ Greene, Early English Carols (n. 2 above) clxv. 
An aungell fro heuen gan lyth;

A greth a maydyn that was so bryth;

A treu knot ther was knyt

Betwyn them both in Trinyte.

(lines 1-4)

That an angel "gan lyth" on "a maydyn" (lines 1-2) directly recalls Gabriel's descent as described in Luke 1.26-38. ${ }^{54}$ This account of the Annunciation had long been invested with great theological import as the Angelic Salutation was generally understood as having initiated the Incarnation, thought by some to be effected through the conceptio per aurem upon Mary hearing Gabriel's greeting. ${ }^{55}$ By the later Middle Ages the narrative would have been frequently encountered in a devotional context through the Ave Maria, which was incorporated into the Little Office of the Blessed Virgin Mary and thus a staple of many fifteenth-century Books of Hours. ${ }^{56}$ In keeping with this devotional emphasis, the carol seeks to highlight Mary's unique status by employing a range of familiar epithets which denote her nobility. We are initially told that Gabriel greets her (line 2), which not only evokes the contemporary emphasis on Mary as queen of heaven, but also serves to highlight the royal ancestry of Christ. ${ }^{57}$ Mary's exalted status was due in part to her marriage to Joseph, whose noble lineage was emphasized in the patrilineal genealogies of Matthew 1.1-17 and Luke 3.23-38, and which was reaffirmed by the patristic exegesis of Isaiah 11.1: "And there shall come forth a rod out of the root of Jesse, and a flower shall rise up out of his root." From the earliest centuries of the Church this verse was interpreted as a reference to Christ's descent from Jesse, the father of David, through Mary; as Tertullian writes: "the root of Jesse is the family of David, and the stem of the root is Mary descended from David, and the blossom of the stem is Mary's son, who is called Jesus Christ." By the later period this noble lineage was a theological commonplace, given visual expression in the popular iconographic image of the Tree of Jesse, which presented Christ's matrilineal ancestry in the form of a large tree or vine. ${ }^{59}$ The carol's emphasis on Mary's nobility subtly recalls this iconographic tradition and is complemented further by the description of her as "bryth" (line 2), which recurs in many Mariological lyrics of the period. ${ }^{60}$ Although the radiance of the Virgin is extolled in a number of

${ }^{54}$ See also Matt $1.18-21$.

${ }^{55}$ This idea is found at least as early as Proclus; see Nicholas Constas, Proclus of Constantinople and the Cult of the Virgin in Late Antiquity: Homilies 1-5, Texts and Translations (Leiden 2003) 273-314. See also Origen, Homiliae in Lucam 7, PG 13.1817-1819; Augustine, Sermo 196. 1, PL 38.1019. On the iconographic depiction of the Annunciation, see Leo Steinberg, "How Shall This Be?': Reflections of Filippo Lippi’s Annunciation in London, Part I," Artibus et Historiae 8 (1987) 25-44.

${ }^{56}$ See Eamon Duffy, The Stripping of the Altars: Traditional Religion in England c. 1400-1580, 2nd ed. (New Haven and London 2005) 210-211, 256-257.

${ }^{57}$ See MED (n. 13 above), s.v. "gret" (adj), definition 3 (a).

${ }^{58}$ Tertullian, De carne Christi, 21. 5, CCSL 2.912; trans. Ante-Nicene Fathers: The Writings of the Fathers down to A.D. 325, ed. Alexander Roberts and James Donaldson, 10 vols. (Oxford 1885) 3, 541. See also Ambrose, De spiritu sancto, 2. 5. 38, CSEL 79.101; Bernard of Clairvaux, Sermo 47. 5, Sermones super cantica canticorum, Sancti Bernardi Opera, ed. Jean Leclercq, Henri Rochais and Charles H. Talbot, 8 vols. in 9 (Rome 1957-1977) 2.64.

${ }^{59}$ See Arthur Watson, "The Speculum Virginum with Special Reference to the Tree of Jesse," Speculum 3 (1928) 445-469 and The Early Iconography of the Tree of Jesse (Oxford 1934); Michael D. Taylor, "A Historiated Tree of Jesse," Dumbarton Oak Papers 34 (1980-1981) 125-176.

${ }^{60}$ See Swete lady, now ze wys, in Brown, Religious Lyrics of the Fifteenth Century (n. 52 above) 107, line 17: "my lady br3th," and As I lay vp-on a nyth, 108, line 2: "a berd so brith." 
Mariological settings, the motif appears most frequently in relation to the Annunciation or the Nativity. Indeed, this association is apparent not only in the Middle English lyric, but also in a dramatic context, as demonstrated by the N-Town play of the Salutation and Conception. Here, Mary's radiance is imbued with a literalism not found in the laudatory epithets of the lyrics, as Joseph states that he finds it difficult to look directly at his wife because of her shining face: "Me merveylyth wyff surely, zour face I can not se, / but as pe sonne with his bemys, quan he is most bryth." ${ }^{\prime 61}$ Yet, the shared focus on Mary's radiance once the Incarnation has occurred illustrates that she is indeed "full of grace," as Luke 1.28 tells us, while also affirming her exalted role as Theotokos.

Having introduced these topoi associated with the Annunciation, the author of $A n$ aungell fro heuen gan lyth goes on to focus on the knot motif, relating it specifically to the Incarnation: "A treu knot ther was knyt / Betwyn them both in Trinyte" (lines 34). Although the context which informs the presentation of this motif is clear, there is nonetheless a certain ambiguity surrounding the meaning of these lines. On the one hand, the author may be using the metaphor of knitting to refer to the union of Christ and the Holy Spirit, in accordance with the belief that Christ became incarnate of the Virgin by the power of the Spirit overshadowing her, as described in Luke 1.35, and later reaffirmed not only in the Nicene Creed, but also in the Apostles' Creed: "conceived by the Holy Ghost, born of the Virgin Mary." 62 However, we might also interpret these lines as a reference to the knot forged between Mary and Christ at the moment of conception, which was only made possible through the power of the Trinity. When read in this light, the carol's use of the words "knot" and "knyt" (line 3) serves to remind us that the substance of Christ's humanity is derived from his mother because he is "born after the flesh of a Virgin," as Augustine puts it. ${ }^{63}$ In evoking the idea of the knitting or weaving of Christ's flesh from that of Mary, the carol draws on a popular strand of religious commentary that can be traced back to Proclus of Constantinople and his influential Homily on the Holy Virgin Theotokos. According to Nicholas Constas, this homily formed part of "the great Marian festival established in Constantinople during the second decade of the fifth century," and was subsequently attached as a supplement to the Acts of the Council of Ephesus in 431, from whence it derived longstanding currency. ${ }^{64}$ Although the homily employs a range of metaphors which celebrate the importance of Mary and her role in the Incarnation, one of the most remarkable is that which compares the Virgin to a sacred loom, on which the body of Christ was woven:

She who called us here today is the Holy Mary ... the awesome loom of the divine economy upon which the robe of union was ineffably woven. The loom-worker was the Holy Spirit;

${ }^{61}$ The Play of the Salutation and Conception, The N-Town Play: Cotton Vespasian D. 8, ed. Stephen Spector, Early English Text Society s.s. 11-12, 2 vols. (Oxford 1991) 1.124, lines 15-16. See also Gail McMurphy Gibson, Theater of Devotion: East Anglian Drama and Society in the Late Middle Ages (Chicago 1989) 147, 153-154.

${ }^{62}$ Creeds of Christendom (n. 9 above) 1.21 .

${ }^{63}$ De santa virginitate, 6, CSEL 41.239-240; trans. Arthur West Hadden, Nicene and Post-Nicene Fathers 1.3, 419. See also Gregory of Thaumaturgus, De fide capitula duodecim 4, PG 10.1130.

${ }^{64}$ Constas, Proclus of Constantinople (n. 55 above) 127, 129. 
the wool-worker the overshadowing power from on high. The wool was the ancient fleece of Adam; the interlocking thread the spotless flesh of the Virgin. ${ }^{65}$

By the later Middle Ages the prevalence of this metaphor, particularly in an iconographic context, was further informed by the renewed interest in the apocryphal legend of the Virgin's life found in the second-century Protoevangelium of James, which became increasingly popular from the twelfth and thirteenth centuries onward. Here, Mary is portrayed as a clothmaker, spinning purple and scarlet wool in order to make a new curtain for the tabernacle, as the Holy Spirit descends upon her at the Annunciation. ${ }^{66}$ Due to the popularity of this text, the presentation of Mary as both a literal and metaphorical clothmaker was a familiar conceit in both the art and literature of the later medieval period. Indeed, devotional writers commonly refer to Christ being "clothed" in his flesh, while Mary was often depicted spinning, seated at a loom weaving or sewing, in images of the Annunciation and, by the fifteenth century, in images of Joseph's Doubt. ${ }^{67}$

However, although the carol's use of the word "knyt" serves to evoke this tradition, we are not encouraged to dwell at length on the image of Mary as clothmaker. Rather, the doctrinal emphasis is placed on the concept of Mary as camera trinitatis. The idea that Mary conceived the fullness of the Godhead "in Trinyte" (line 4), rather than Christ alone, is evident from the seventh century, but, as Melissa R. Katz has pointed out, it became popular during the later Middle Ages due to Adam of St Victor's hymn Salve, Mater Salvatoris, in which the Virgin is described as the "totius Trinitatis / Nobile Triclinium." ${ }^{68}$ By the fifteenth century the idea of Mary as the chamber of the Trinity was given devotional expression through the tradition of the Schreinmadonna or Vierge ouvrante. ${ }^{69}$ Some of these statues of the Virgin, such as a Rhenish example (ca. 1300) that is now in the Metropolitan Museum of Art, New York, open to reveal the Gnadenstuhl or Throne of Grace (Fig. 4): an image of the Trinity in which God the Father supports the crucified Christ, while the Holy Spirit hovers above in the form of a dove. ${ }^{70}$ The carol's portrayal of Mary as camera trinitatis may well recall this type of Vierge ouvrante; this is also likely in the Shearman and Taylor's Corpus Christi

${ }^{65}$ Ibid. 137.

${ }^{66}$ See New Testament Apocrypha, ed. E. Hennecke and W. Schneemelcher, trans. R. McL. Wilson, 2 vols. (London 1963-1965) 1.370-388. See also Elizabeth Coatsworth, "Cloth-making and the Virgin Mary in Anglo-Saxon Literature and Art," Medieval Art: Recent Perspectives. A Memorial Tribute to C .R. Dodwell, ed. Gale R. Owen-Crocker and Timothy Graham (Manchester 1998) 8-25.

${ }^{67}$ For examples of such images in the visual arts, see Gibson, Theater of Devotion (n. 61 above) 161166; Gertrud Schiller, Iconography of Christian Art, trans. Margaret Seligman, 2 vols. (London 1972) 1.5658.

68 "Noble dining hall of the entire Trinity," (my trans.). "Salve, Mater Salvatoris," Analecta Hymnica Medii Aevi, ed. G. M. Dreves, C. Blume, and H. M. Bannister, 55 vols. (Leipzig 1886-1922) 54.383-384. See Melissa R. Katz, "Behind Closed Doors: Distributed Bodies, Hidden Interiors, and Corporeal Erasure in Vierge ouvrante Sculpture," RES: Anthropology and Aesthetics 55-56 (2009) 194-221, esp. 200.

${ }^{69}$ On the tradition of the vierge ouvrante or Schreinmadonna, see Christoph Baumer, "Die Schreinmadonna," Marian Library Studies 9 (1977) 237-272; Gudrun Radler, Die Schreinmadonna "Vierge Ouvrante": Von den bernhardinischen Anfängen bis zur Frauenmystik im Deutschordensland (Frankfurt am Main 1990). See also Barbara G. Lane, The Altar and the Altarpiece: Sacramental Themes in Early Netherlandish Painting (New York 1984) 27-28; Barbara Newman, Gods and Goddesses: Visions, Poetry and Belief in the Middle Ages (Philadelphia 2003) 269-273.

${ }^{70}$ See Anne Marie D'Arcy, Wisdom and the Grail: The Image of the Vessel in the Queste del Saint Graal and Malory's Tale of Sankgreal (Dublin 2000) 263-264, 301. 
pageant, where, as noted above, it is stated that God was "conseyvide in Trenete" in Mary's womb. In evoking this image, the carol's author reaffirms the unity of the Trinity and the role of the triune Godhead in the Economy of Salvation. Moreover, the audience is not only encouraged to focus on the devotional significance of the Annunciation and Mary's role as Theotokos, but also to contemplate the Trinitarian theology which underpins the doctrine of the Incarnation, a point that is further reinforced by the repetition of the burden which would follow the first stanza.

The carol's second stanza turns away from the Annunciation in order to focus on the Crucifixion. Although this movement is in keeping with the Apostles' Creed, the carol seeks to establish a link with the Incarnation alluded to in the previous stanza, as Christ is initially portrayed not as a man, but as a "fayyrly fod," who "bled his hart blod" (lines 5-6) in order to save mankind. By describing Christ as a "fod," a term which could mean both "a young child, baby" as well as "spiritual sustenance," "71 the carol's author introduces a subtle juxtaposition between the innocence of the Christ child and the severity of his bloody sacrifice on the Cross. In so doing, the carol conforms to a contemporary devotional tradition which associated the Incarnation with the Passion. As Leah Sinanoglou notes, "Medieval writings, from early Latin tracts to late English popularizations, persist in conflating the Incarnation and the Passion, in fusing the Babe of Bethlehem and the sacramental Victim of the Mass., ${ }^{, 72}$ In the Latin West, the tradition of viewing the Christ child in sacramental terms is found at least as early as Augustine, who describes the Christ child in the manger as spiritual nourishment; the infant Jesus is the "food of the faithful beasts of burden." "73 By the later Middle Ages the belief that the Christ child was present in the Eucharist became increasingly popular, particularly in the form of what was commonly known as the "child-host miracle." This tradition has its origins in the so-called Vitae patrum, a popular text compiled from third and fourth-century sources and later edited by the seventeenth-century Bollandist, Heribert Roswede. ${ }^{74}$ By the fifteenth century the practice of meditating on this Eucharistic miracle was actively encouraged; thus the carol's description of the body of Christ as "fayyrly fod" (line 5) not only serves to arouse compassion in the audience by encouraging them to visualize this selfless sacrifice on the altar, but also recalls the popular contemporary vision of the Christ Child in the consecrated host. ${ }^{75}$

\footnotetext{
${ }^{71}$ MED (n. 13 above), s.v. "fode" (n2), definition 1 (a) and (n1), definition 2 (a).

${ }^{72}$ Leah Sinanoglou, "The Christ Child as Sacrifice: A Medieval Tradition and the Corpus Christ Plays," Speculum 48 (1973) 491-509; see the rev. ed. as Leah H. Marcus in The Christ Child in Medieval Culture: Alpha es et O!, ed. Mary Dzon and Theresa M. Kenney (Toronto 2012) 3-28. All references are to the original article.

${ }_{73}$ Augustine, Sermo 9, PL 38.1008; trans. Thomas Comerford Lawler, Saint Augustine, Sermons for Christmas and Epiphany, Ancient Christian Writers 15 (New York 1952) 104. See also Theresa Kenney, "The Manger as Calvary and Altar in the Middle English Nativity Lyric," The Christ Child in Medieval Culture, ed. Dzon and Kenney (n. 72 above) 48.

${ }^{74}$ In addition to Sinanoglou, "Christ Child," (n. 72 above) 493, see Miri Rubin, Corpus Christi: The Eucharist in Late Medieval Culture (Cambridge 1991) 135-139. See also Paschasius Radbertus, De corpore et sanguine Domini, PL 120.1319-1320; William Durandus, Liber de corpore et sanguine Christi, 8, 28, PL 149.1418; Gerald of Wales, Gemma Ecclesiastica, 1, 11, Giraldi Cambrensis Opera, ed. J. S. Brewer, J. F. Dimock, and G. F. Warner, Rolls Series 21, 8 vols. (London 1861-1891) 2.38-43.

${ }^{75}$ See, for instance, The Lay Folks Mass Book or the Manner of Hearing Mass, ed. Thomas Frederick Simmons, Early English Text Society o.s. 71 (London 1879) 22-23, cited by Sinanoglou, "Christ Child," (n. 72 above) 497.
} 
Although the description of Christ as a "fayyrly fod" (line 5) serves a devotional purpose in its own right, the emotive force of the image is reinforced by the introduction of the knot motif in the final line of the stanza. Indeed, by echoing the reference to the future sufferings of the Christ child, the image of the knot acts as a metaphor for the wounds inflicted on Christ at the Crucifixion: "The knottes war knit with nales iii" (line 8). While the reference to the "nales iii" is crucial to unlocking this knot-wound metaphor, the description is also noteworthy on an iconographic level, as it not only evokes the standard contemporary image of Christ pinned to the cross with three nails (one through each of his hands and the other through his feet), but also recalls the popular iconographic tradition of the arma Christi, which encouraged the individual to meditate on the specific instruments of Christ's Passion. ${ }^{76}$ Moreover, the author's visualization of the wounds as "knottes" may also call to mind the carved stone or wooden roof bosses which were a typical ornamental feature of Gothic vaulting and, significantly, could also be known as "knottes." "77 it is interesting to note that many fifteenth-century examples portray the popular contemporary motif of the shield of the Five Wounds, found, for instance, in Winchester Cathedral. ${ }^{78}$ This range of iconographic examples highlights the subtle devotional potential implicit in the carol's knotwound metaphor, which directs the audience to recall images and motifs particularly related to the iconographic tradition of the Five Wounds. ${ }^{79}$ Yet the knot-wound analogy is also invested with a deeper, theological significance in the carol, as in the preceding line the Passion is described in terms of a battle that Christ sees through to its bitter conclusion: "Qwan he was don on the rod / The knottes war knit with nales iii" (lines 7-8). Although the audience is exhorted to focus on Christ's wounds to some extent, the last two lines of the stanza work in tandem, encouraging the audience to interpret the "knotte" in terms of the salvific outcome of Christ's sacrifice. ${ }^{80}$ We are reminded that even though Christ's wounds testify to the ferocity of his suffering and should thus arouse our compassion on a devotional level, from a theological perspective they are battle scars he must endure in order to secure mankind's salvation through his victory on the Cross.

While the knot motif continues to be associated with specific aspects of the Economy of Salvation in stanzas three and four, the use of the term "knotte" to describe the "result" or "outcome" of Christ's sacrifice continues to inform the theological import of the carol. The soteriological significance of Christ's death is heightened by a subtle shift in emphasis from the beginning of the third stanza; the author turns away from Christ's earthly life in order to focus more explicitly on his divinity. This sequence of events parallels the order of the Economy of Salvation found in the Apostles' Creed

\footnotetext{
${ }^{76}$ On the depiction of Christ fixed to the cross with three nails, see Schiller, Iconography (n. 67 above) 2.146. On the arma Christi, see Rudolf Berliner, "Arma Christi," Münchner Jahrbuch der bildenden Kunst 6 (1955) 35-152; Schiller, Iconography (n. 67 above) 2.184-197.

${ }^{77}$ See MED (n. 13 above), s.v. "knotte" (n), definition 4 (b): "an embossed ornament of wood or stone on a wall, pillar, ceiling, etc.; an embossed ornament on or under a roof."

${ }^{78}$ See Charles John Philip Cave, Roof Bosses in Medieval Churches (Cambridge 1948) fig. 240.

${ }^{79}$ On the devotional tradition of the Five Wounds, see Douglas Gray, "The Five Wounds of Our Lord," Notes and Queries 208 (1963), 50-51, 82-89, 127-134, 163-168.

${ }^{80}$ See MED (n. 13 above), s.v. "knotte" (n), definition 2 (b) and 2 (c), where the term can mean "the conclusion of a statement, book, story, song etc.," or "the result of a battle, outcome."
} 
whereby the attention of the audience is directed towards the Resurrection: "Wettnes of apostyll Johan: / He rose hup and wold gon" (lines 9-10). To underscore the veracity of this divine event the author not only employs plain language, but also invokes the authority of John's role as witness to the Crucifixion and the Resurrection. ${ }^{81}$ This emphasis on the reality of the Resurrection is highlighted in the final lines of the third stanza, which reminds the audience of the events of Christ's earthly burial, while also emphasizing his divine power: "The knot was knyt with marbyl ston / Thorow the vertu of the Trinyte" (lines 11-12). The idea that the knot was "knyt" with "marbyl ston" (line 11) serves to recall the tomb of Christ, as the metaphor of knitting is, on one level, deployed to draw attention to the sealing of the tomb. This is in accordance with the synoptic gospels which describe the tomb as "hewed out of rock" and sealed with a "great stone" (Matthew 27.59). ${ }^{82}$ The reference to the "marbyl ston" (line 11) also subtly evokes the tradition of the Stone of Unction: the name given to the stone on which the body of Christ was anointed before burial. ${ }^{83}$ As Gertrud Schiller points out, the image of the crucified body in repose on the Stone of Unction has its origins in the iconography of the Eastern Church, where it is frequently displayed on embroidered cloths, known as epitaphioi, used in the liturgy. ${ }^{84}$ Devotional interest in the Stone of Unction can be traced back to its arrival in Constantinople in 1169-1170 at the behest of Emperor Manuel Komnenos I, where it was displayed as a relic. ${ }^{85}$ Although this stone has since been lost, a second stone, also declared as the true Stone of Unction, remained on display in the Church of the Holy Sepulcher in Jerusalem, from at least the fourth century until the present day. Like the stone in Constantinople, the stone in the Holy Sepulcher was revered as a precious relic, attracting such pilgrims as the Russian Abbot Daniel who describes the holy sites of Jerusalem in 1106, including "This sacred rock, which all Christians kiss."

The devotional significance of both stones was enhanced by a legend surrounding the stone in Constantinople, which claimed that this block of red marble with white veining had been miraculously stained by the blood of Christ and the tears of the Virgin. In the eyes of the devout, as Mary Ann Graeve notes, "the red marble, with streaks of white running through it, would have commemorated the commingling of tears and sacred blood." ${ }^{87}$ Indeed, due to the emphasis placed by the Latin Church on Christ's corporeal suffering during the later Middle Ages, the Stone of Unction became an increasingly popular devotional motif throughout the fifteenth century and

${ }^{81}$ See John 19.26-27 and 20.19-29.

${ }^{82}$ See Mark 15.46; Luke 23.53; John 19.39.

${ }^{83}$ Although the use of such a stone is not mentioned explicitly in the Gospel narratives, the anointing of the body of Christ is recounted in John 19.39-40. The synoptic Gospels state that Christ's body was wrapped in linen before burial; see Matt 27.59; Mark 15.46; Luke 23.53.

${ }^{84}$ See Didron, Christian Iconography (n. 23 above) 2.173.

${ }^{85}$ See Nicetas Choniates, De Manuele Comneno 8, PG 139.571-574; and John Cinnamus, Historiam 6, PG 133.645-647. On the stone in Constantinople, see George P. Majeska, Russian Travelers to Constantinople in the Fourteenth and Fifteenth Centuries (Washington, DC 1984) 292-293; Cyril Mango, "Notes of Byzantine Monuments," Dumbarton Oaks Papers 23/4 (1969-70) 369-375.

${ }^{86}$ The Pilgrimage of the Russian Abbot Daniel in the Holy Land, trans. C. W. Wilson, Palestine Pilgrims' Text Society 4 (London 1895) 12.

${ }^{87}$ Mary Ann Graeve, "The Stone of Unction in Caravaggio's Painting for the Chiesa Nuova," Art Bulletin 40 (1958) 228. 
into the early modern period, featuring prominently in images of Christ's burial and entombment. ${ }^{88}$ This is particularly true of the art of Northern Europe, where the Stone of Unction was often identified with the stone that sealed Christ's tomb or sarcophagus. ${ }^{89}$ In the painting, The Three Marys at the Tomb, generally attributed to Hubert and/or Jan van Eyck (ca. 1425-1435, Rotterdam: Museum Boijmans van Beuningen), the lid of the sarcophagus is painted red in order to evoke the red stone at Constantinople. ${ }^{90}$ The artistic conflation of the Stone of Unction and the rock which sealed Christ's tomb is discernible in the carol's presentation of the motif: the reference to the "marbyl ston" (line 11) not only evokes the tomb from which Christ was resurrected, as it serves as the "knotte" or "bond" which sealed the tomb, but it also encourages the audience to visualize Christ's motionless body on the Stone of Unction in line with contemporary devotional practice. ${ }^{91}$ This multiplication of senses is sustained in the final line of the stanza, where the audience is reminded that the "knotte" or "outcome" of Christ's death is accomplished, or "knyt," only "Thorow the vertu of the Trinyte" (line 12). This line reinforces the message of the carol's burden, reminding us that it is the "vertu" or "divine power" of the triune Godhead which is responsible for the salvation of mankind.

That it is the divine power of the Trinity which effects the salvation of man is emphasized further in stanza four, which, in accordance with the carol's sequential progression through the Apostles' Creed, concentrates on Christ's reception into the kingdom of heaven, where he is seated at the right hand of the Pater omnipotens: "On Scher Thursday he steyd to heuen / Hys Fader hym blyssyd with myld steuen" (lines 13-14). Although the acknowledgment that Christ "steyd" or ascended to "heuen" clearly refers to the Ascension, the use of the term "Scher Thursday" is somewhat curious, as this phrase is used more typically to refer to Holy Thursday during Easter week. ${ }^{92}$ However, the phrase is perhaps not as incongruous in the context of stanza four as it might initially appear. The feast of the Ascension is traditionally celebrated on the fortieth day of Easter, in accordance with the chronology of Acts 1.3, so falls on a Thursday, and was also known as Holy Thursday. ${ }^{93}$ Certainly, the opening lines of stanza four clearly affirm the mystery of the Ascension, as demonstrated by the deployment of the term "steyd" (deriving from the verb "stien," "to ascend"), while the use of "steuen" was commonly employed to refer to the "voice" of God. ${ }^{94}$ The description of God the Father blessing the Son in a "myld" (line 14) or merciful voice is significant because it recalls those scriptural occasions on which Christ is

\footnotetext{
${ }^{88}$ Ibid. 228.
}

${ }^{89}$ Ibid. 232.

90 See Erwin Panofsky, "The Friedsam Annunciation and the Problem of the Ghent Altarpiece," Art Bulletin 17 (1935) 437 n. 8.

${ }^{91}$ See MED (n. 13 above), s.v. "knotte" (n), definition 3 (a).

${ }^{92}$ Ibid. s.v. "shere thuresdai" (phr); "shire thuresdai" (phr); "shrof-thuresdai" (n).

${ }^{93}$ On the use of the term Holy Thursday for both the Thursday of Holy Week and Ascension Thursday, see Robert Thomas Hampson, Medii Avi Kalendarium: or Dates, Charters, and Customs of the Middle Ages (London 1841) 200.

${ }^{94}$ See MED (n. 13 above), s.v. "stien" (v), definition 1c (b): “of Christ: to ascend bodily (to heaven following the Resurrection)"; s.v. "steven(e)" (n), definition 1 (b): "the voice of God or of the Holy Ghost." 
acknowledged as "my beloved Son, in whom I am well pleased" (Matt 3.17). ${ }^{95}$ It also evokes the iconographic type of the Gnadenstuhl, which originated in the twelfth century but became especially popular during the later period. The Gnadenstuhl appears across a number of mediums, including sculpture, stained glass, and manuscript illustration, as a decorated initial in the thirteenth-century Carrow Psalter demonstrates. ${ }^{96}$ The prominence of this image during the later medieval period is perhaps due to its meditative potential, as by encouraging the audience to witness the Father receiving his Son who was offered up in propitiation, it underlines the importance of the three persons in the Economy of Salvation. As Gesa Thiessen notes, the Father offers "his Son as a sacrifice for the redemption of humankind while at the same time he takes his Son back, thus accepting the Son's sacrifice for the sins of humankind. The image therefore makes transparent the self-giving of the divine persons, the economic Trinity." 97 In line with the Trinitarian significance of the Gnadenstuhl, the final lines of the carol's fourth stanza reaffirm the role of the three persons in the Economy of Salvation: "For to fulfyl the deddes wyll, / The knot was knit with persons iii" (lines 15-16). ${ }^{98}$ These lines, which appear to refer to the Harrowing of Hell, remind us that in order for the righteous souls in bondage to be united with God, the knot of salvation must be secured through the power of the Trinity. Here, it is worth noting that while the previous stanzas ascribed the knot of salvation to the work of Christ, thus conforming to the popular tendency to attribute certain divine acts to particular persons of the Godhead, at this point the carol places greater emphasis on the indivisibility of the Trinity, as in the burden. ${ }^{99}$

In keeping with the thematic structure of the Apostles' Creed, the carol's final stanza turns to focus on the Parousia and the Last Judgment: "God xal rysyn at domusday / Hys v knottes for to spray" (lines 17-18). Although the reference to "God" can be seen to echo the emphasis on the indivisibility of the Trinity in the previous stanza, the description of the wounds as "knottes" in the next line specifically recalls the hieratic image of the glorified Christ as Judex Justus. In medieval depictions of the Last Judgment, the Risen Christ is often depicted as Salvator Mundi, or

\footnotetext{
${ }^{95}$ See also Mark 1.11; Luke 3.22; and the words spoken by God the Father at the Transfiguration (Matt 1.5; Mark 9.6; Luke 9.35).

${ }^{96}$ Carrow Psalter, Baltimore, Maryland, Walters Art Gallery MS W. 34, fol. 200r (East Anglia, ca. 1250). See M. R. James, A Descriptive Catalogue of the Second Series of Fifty Manuscripts (nos. 51-100) in the Collection of Henry Yates Thompson (Cambridge 1902) 2-11; Nigel Morgan, Early Gothic Manuscripts (II), 1250-85 (London 1988) 88-89. For the Gnadenstuhl in sculpture, see John Block Friedman, Northern English Books, Owners, and Makers in the Late Middle Ages (Syracuse, NY 1995) 175-186. For the Gnadenstuhl in stained glass, see John A. Knowles, Essays in the History of the York School of GlassPainting (London and New York 1936) 171-172; Alexandra Barratt, "No such sitting': Julian Tropes the Trinity," A Companion to Julian of Norwich, ed. Liz Herbert McAvoy (Cambridge 2008) 50.

${ }^{97}$ Gesa Thiessen, "Images of the Trinity in Visual Art," Trinity and Salvation: Theological, Spiritual and Aesthetic Perspectives, ed. Declan Marmion and Gesa Thiessen (Oxford and Bern 2009) 130. See also Schiller, Iconography (n. 67 above) 2.123.

${ }^{98}$ According to Greene, the word "wyll" is an "obvious corruption" and originally "the rhyme-word was probably 'seven"” (Early English Carols (n. 2 above) 414). This suggestion rests on the assumption that the scribe confuses the word dedde ("deed") for ded ("dead," which can also be spelt dede). If Greene is correct, the original description of the "dedes seven" may well have been a reference to the seven works of mercy. If this is a deliberate scribal emendation, it may be indicative of a desire to highlight Christ's redemption of mankind through the Harrowing of Hell.

${ }^{99}$ See Augustine, De Trinitate, 1. 4, CCSL 50.36; trans. Nicene and Post-Nicene Fathers 1.3, 20.
} 
Savior of the World, who not only adopts the gesture of the ostentatio vulnerum, but is also clad in an exomis tunic, which draws attention to his bare side and the side wound in particular. ${ }^{100}$ In contrast to the contemporary devotional image of the Man of Sorrows who displays his wounds to incite pathos in the viewer, the ostentatio vulnerum gesture was traditionally invested with a theological significance in the context of the Last Judgment. As Aquinas reminds us, the wounds reveal Christ's divine strength and "indicate the exceeding power whereby Christ overcame his enemies by his Passion and infirmity." "The power of the Judex Justus is reaffirmed in the final lines of the stanza, where Christ addresses the audience through direct speech: "To al men he xal say, / 'Lo, man, what knot I knyt for the"' (lines 19-20). This directive encourages the audience to visualize each wound as a "knot," in keeping with the previous image of the "v knottes" on line eighteen. However, the association once again of knots with knitting may also recall here the popular devotional concept of the nodus amicitiae or "knot of friendship." Although this idea has its origins in Aelred of Rievaulx's Mirror of Charity, it was particularly popular in the writings of fourteenth and fifteenth-century mystics, where it is often evoked to express the desire for divine union with God. ${ }^{102}$ Indeed, in the fifteenth-century translation of Richard Rolle's Fire of Love, the text's first-person narrator implores Christ with the words, "O swete Ihesu, pi lufe in me I bynde with a knot vnabyll to be lowsyd." 103 In the Showings of Julian of Norwich, however, the motif is used to different effect, demonstrating the inextricable bond, or "oneing," that exists between man and God: "he wyll we wytt that this deerwurthy soule was preciously knytt to hym in the makyng, whych knott is so suttell and so myghty that it is onyd in to god." 104

Although the final lines of the carol may recall the allusive language of the mystical tradition, the author's subtle evocation of the nodus amicitiae carries a clear theological message. Christ's directive forces the audience to recall the various manifestations of the "knot" deployed in the carol up to this point: we are encouraged to consider every aspect of Christ's sacrifice simultaneously, from the Incarnation and Passion to the Burial and Resurrection. Indeed, the final line encapsulates the Economy of Salvation as outlined in the carol's five stanzas, symbolized by the final variation on the Trinitarian knot motif: the knot of love knitted for the salvation of mankind by the power of the triune Godhead. Thus, we return, full circle, to the message of the burden: "Of al the knottes that I se / I prese the knot in Trinite" (lines a-b). The final

\footnotetext{
${ }^{100}$ On the iconography of the Last Judgment and the ostentatio vulnerum, see Émile Mâle, Religious Art in France, the Thirteenth Century: A Study of Medieval Iconography and its Sources, ed. Harry Bober, trans. Marthiel Mathews (Princeton 1984) 362-391; Jennifer O’Reilly, "Early Medieval Text and Image: The Wounded and Exalted Christ," Peritia 6-7 (1987-1988) 72-118.

${ }^{101}$ The Summa Theologica of St Thomas Aquinas, Part 3, Issue 7, trans. Fathers of the English Dominican Province (New York 1922) 43.

${ }^{102}$ See Aelred of Rievaulx, Speculum Caritatis 28, PL 195.531. See also Wolfgang Riehle, The Middle English Mystics (London 1981) 51.

${ }^{103}$ Richard Rolle, The Fire of Love, 2.8, The Fire of Love and The Mending of Life or The Rule of Living, translated from the Latin of Richard Rolle by Richard Misyn, ed. Ralph Harvey, Early English Text Society o.s. 106 (London 1896) 88. See also The Incendium Amoris of Richard Rolle of Hampole, ed. Margaret Deanesly (Manchester 1915) 257.

${ }^{104}$ A Book of Showings to the Anchoress Julian of Norwich, ed. Edmund Colledge and James Walsh, 2 vols. (Toronto 1978) 2.560 (Long Text 54, 58-61).
} 
recitation of these lines marks the conclusion of the carol and is particularly fitting, as the movement from the words spoken by Christ at the end of stanza five to the now familiar imagery of the burden, underlines the marrying of the Christological and Trinitarian themes of the lyric: we are reminded once more that the redemption of mankind has been effected not by Christ alone, but by the fullness of God in Trinity.

As has been demonstrated, when read in light of the origin and development of the motif of the Trinitarian knot, it is clear that An aungell fro heuen gan lyth offers a particularly sophisticated understanding of this motif: notwithstanding the traditional use of the Trinitarian knot in the burden, the carol is undoubtedly remarkable in the way it adapts the motif to symbolize the five great mysteries of the faith expressed in the Apostles' Creed. Thus, Greene's suggestion that the carol's knot motif symbolizes "Christ's perfect love" 105 is in need of greater refinement, as a detailed analysis of the poem reveals that it is informed by a far more complex range of devotional and theological concerns that culminate in an orthodox expression of faith. An aungell fro heuen gan lyth stands as a particularly good example of the level of sophistication that some poems in the Middle English religious lyric corpus can reach. It should be noted, however, that the carol's sophistication is not only communicated through its handling of a number of complex, theological ideas, but also through its careful structure, as in spite of the carol's apparent juxtaposition of Trinitarian and Christological concepts, the stanzas and the burden are fully integrated through their shared employment of the knot motif. Indeed, this recurring image is central to the devotional and theological framework of the carol, as it not only directs the audience to meditate on the immediacy of Christ's sacrifice, but also reinforces the carol's central point: the plenitude of the Trinity revealed in the Economy of Salvation. Although the sophisticated deployment of the Trinitarian knot motif in An aungell fro heuen gan lyth is unmatched in the Middle English lyric tradition, it should be noted that the popularity of the motif did not terminate with the end of the Middle Ages. Indeed, the polysemous significance of the Trinitarian knot as a symbol of theological orthodoxy, as well as the inherent creative potential of the motif, ensured that it prevailed in an early modern context. Indeed, John Donne's reference to this motif in his sonnet, "Father, part of his double interest (XII)," bears witness to the enduring popularity of this very medieval conceit:

Father, part of his double interest

Unto thy kingdome, thy Sonne gives to mee,

His joynture in the knottie Trinitie,

Hee keepes, and gives mee his deaths conquest. ${ }^{106}$

\footnotetext{
${ }^{105}$ Greene, Early English Carols (n. 2 above) 413.

${ }^{106}$ John Donne, "Father, part of his double interest (XII)," John Donne: The Divine Poems, ed. Helen Gardner, 2nd ed. (Oxford 1978) 12, line 3. See also "Batter my heart three person'd god (X)," ibid. 11.
} 


\section{APPENDIX}

An Aungell fro heuen gan lyth (Oxford, Bodleian Library, MS Eng. poet. e.1, fol. 31r) ${ }^{107}$

Off al the knottes that I se

I prese the knot in Trinite.

An aungell fro heuen gan lyth;

A greth a maydyn that was so bryth;

A treu knot ther was knyt

Betwyn them both in Trinyte.

After this that fayyrly fod,

For hus he bled his hart blod

Qwan he was don on the rod;

The knottes war knit with nales iii.

Wettnes of apostyll Johan:

He rose hup and wold gon;

The knot was knyt with marbyl ston

Thorow the vertu of the Trinyte.

On Scher Thursday he steyd to heuen;

Hys Fader hym blyssyd with myld steuen,

For to fulfyl the deddes wyll,

The knot was knit with persons iii.

God xal rysyn at domusday

Hys v knottes for to spray;

To al men he xal say,

"Lo, man, what knot I knyt for the."
Of

praise

began to descend

And greets; bright

beautiful child (Christ)

us

When

Witness

up

Through

voice

shall

display

shall

${ }^{107}$ The text of the poem is taken from Greene, Early English Carols (n. 2 above), 175, no. 282. All glosses are my own. 


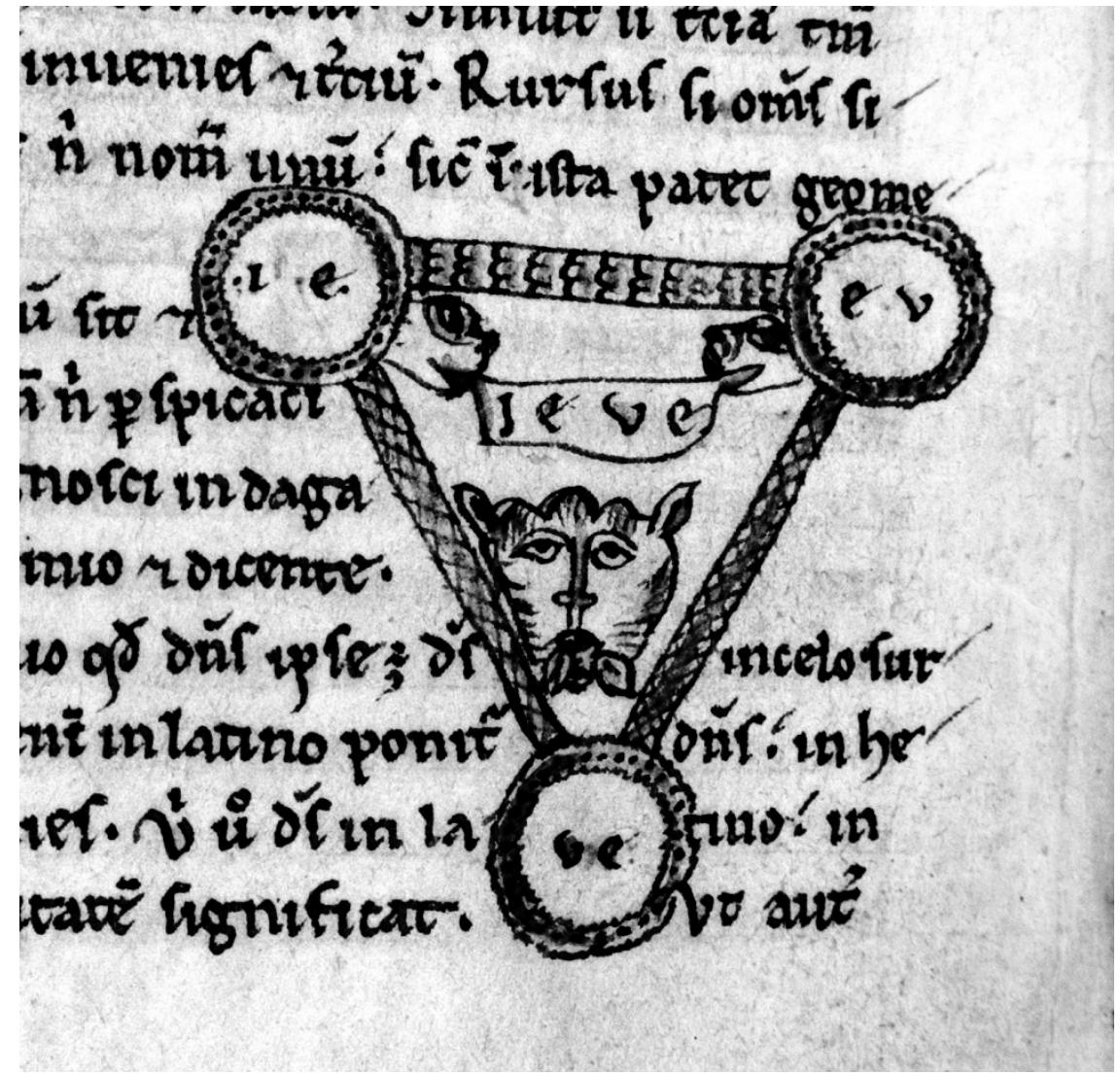

FIG. 1. Petrus Alfonsi, illustration of the Tetragrammaton. (Cambridge, St. John's College MS E.4, fol. 153v, 12th c.). By permission of the Master and Fellows of St. John's College, Cambridge. 


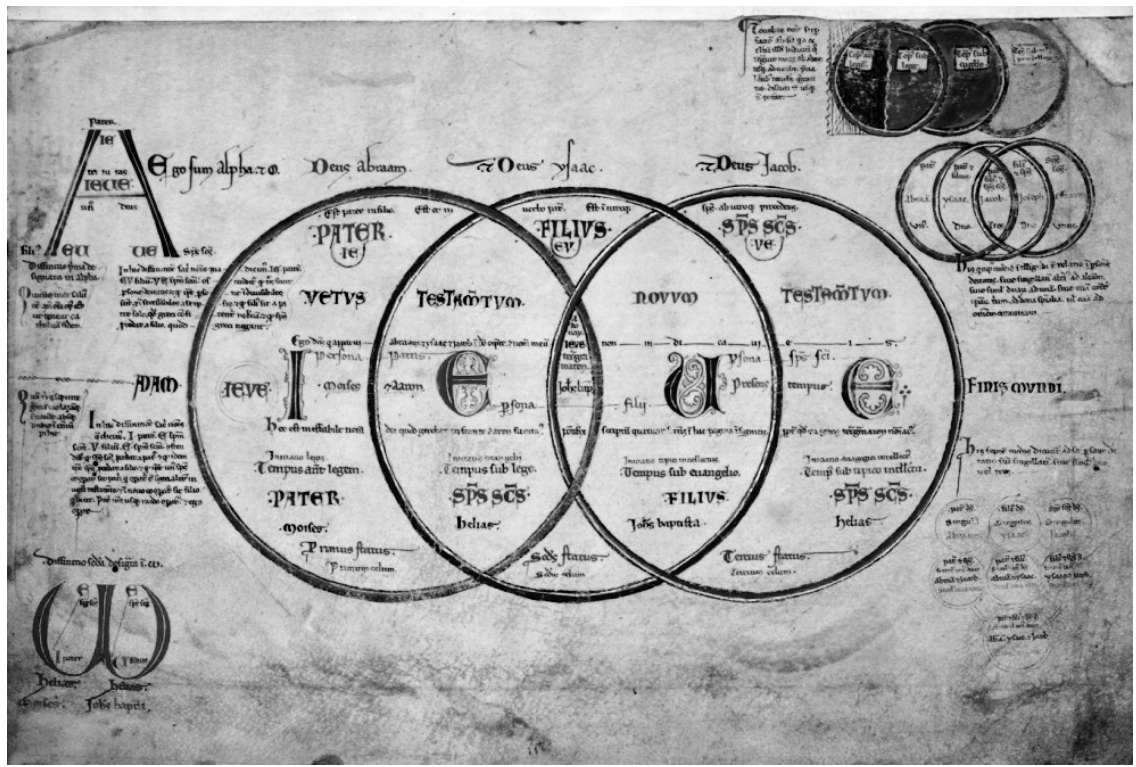

FIG. 2. Joachim of Fiore, illustration of the Trinitarian Rings from the Liber Figuarum. (Oxford, Corpus Christi College MS 255A, fol. 7v, early 13th c.). (C) Corpus Christi College, Oxford. UK Bridgeman Images. 


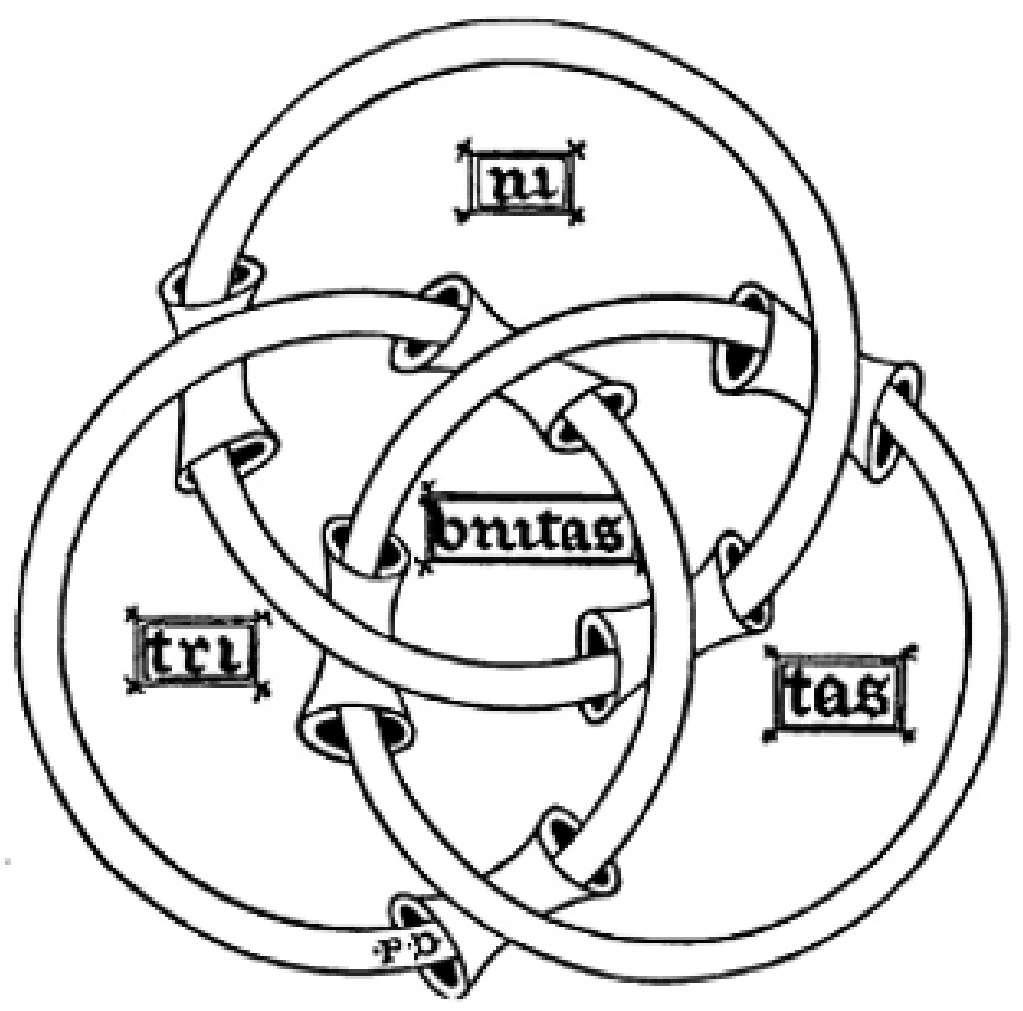

FIG. 3. Aldophe Napoléon Didron, illustration of the Borromean Rings (Chartres, Bibliothèque Communale, MS 1355, late 13th c.; destroyed by fire, 1944), repr. in Christian Iconography: The History of Christian Art in the Middle Ages, trans. Margaret Stokes, 2 vols. (London 1886) 2.46. 


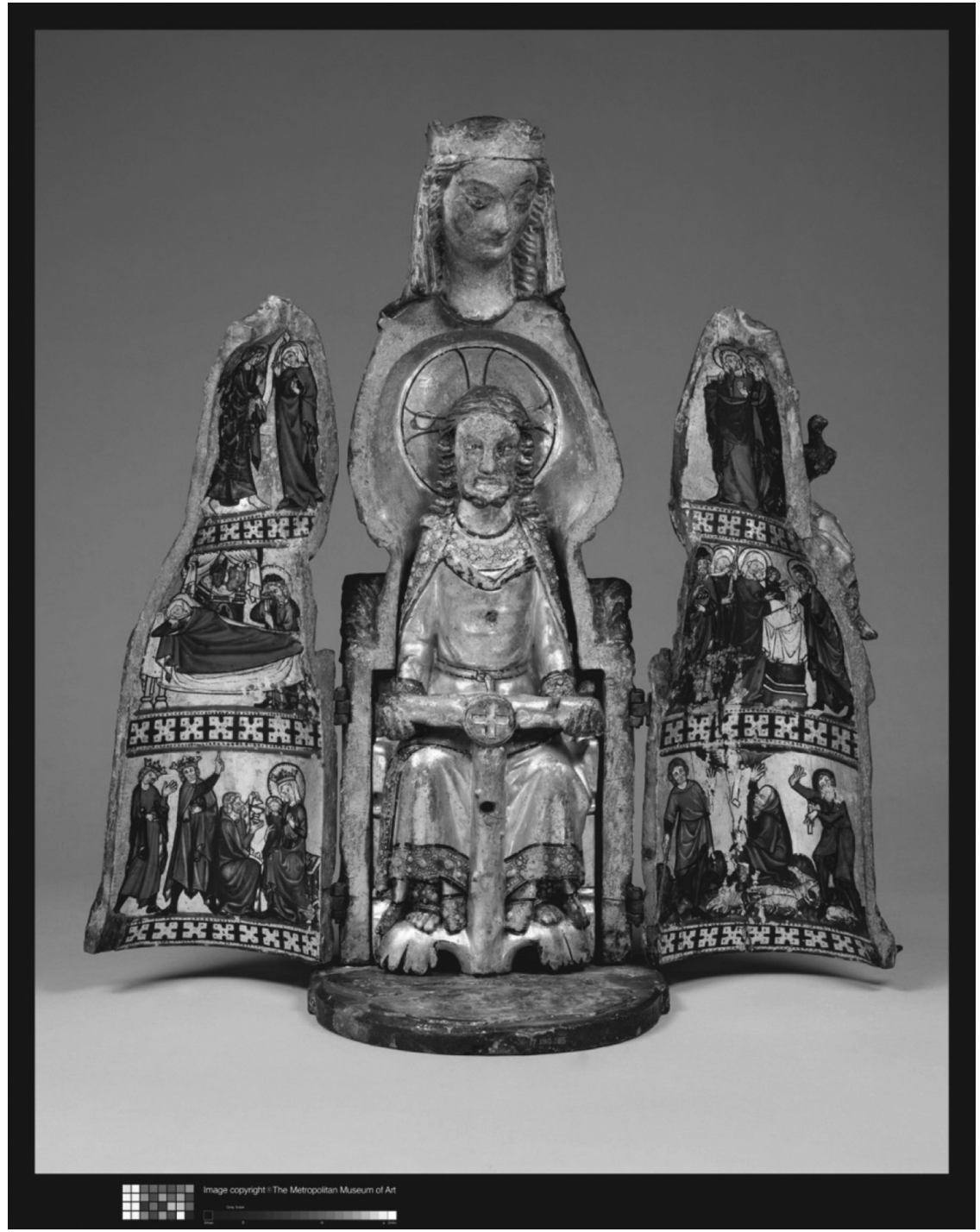

FIG. 4. The Shrine of the Virgin, German (Rhenish). (New York, Metropolitan Museum of Art, ca. 1300). (C) The Metropolitan Museum of Art/Art Resource/Scala, Florence. 
